\title{
ANALISIS RASIO PROFITABILITAS UNTUK MENGUKUR KINERJA BANK BPR HARAU PAYAKUMBUH
}

\author{
FAUZIAH LATIF, JHON FERNOS \\ Akademi Keuangan dan Perbankan "Pembangunan" \\ Email Institusi Pembimbing : Jhonfernos@akbpstie.ac.id
}

\begin{abstract}
From the BOPO ratio of BPR Harau Payakumbuh in 2012 the value of BOPO was $83.19 \%$, in 2013 the value was $84.58 \%$, in 2014 the value was $85.95 \%$, in 2015 the value was $85.53 \%$. That to measure the ability of operating income to cover operating costs, the smaller the BOPO the more efficient the bank is in controlling its operational costs, the greater the profits the bank will get. From the ratio of NPM BPR Harau Payakumbuh in 2012 the value was 14.53\%, in 2013 the value was $13.34 \%$, in 2014 the value was 12.03\%, in 2015 the value was $12.37 \%$. So that the bank's ability to decline in generating net income. If the bigger the better, but this can be used as a representative measure, because the profits obtained must also be compared with the amount of funds used to obtain the profit. From the ratio of ROA to Hajj Payakumbuh in 2012 the value is $2.84 \%$, year 2013 ROA value is $2.61 \%$, in 2014 the value is $2.48 \%$, in 2015 the value is $2.29 \%$. So the BPR of Harau Paykumbuh ROA decreases every year, although the performance of BPR Harau Payakumbuh remains good because its value is still above the average BI assessment. If the ROA is lower the bank will not be able to operate effectively and efficiently in utilizing the assets it has in generating profits. From the 2012 ROE ratio of BPR Harau Payakumubuh the value was $23.52 \%$, in 2013 the value was $22.41 \%$, in 2014 the value was $20.45 \%$, and in 2015 the value was $18.22 \%$. So from 2012 to 2015 there was a decline, so that the bank's ability to generate net income from capital was low. However, the ROE is still said to be good because the value is above the average BI assessment.
\end{abstract}

Keywords : Bank, Analisa Rasio Keuangan, Profitabilitas, Kinerja Keuangan

\section{PENDAHULUAN}

Dalam perkembangan dunia perbankan akhir-akhir ini mengalami kemajuan yang sangat pesat. Peranan bank sangat penting bagi masyarakat Indonesia, karna pada dasarnya perbankan bertujuan untuk menunjang pembangunan nasional dalam meningkatkan kesejahteraan masyarakat. Perkembangan yang sangat pesat ini dialami oleh baik Bank Umum maupun Bank Perkreditan Rakyat, maka setiap Bank bisa meningkatkan profitabilitasnya.

Menurut Undang-undang RI Nomor 10 Tahun 1998 tentang perubahan Undang-undang Nomor 7 Tahun 1992 Bank adalah badan usaha yang menghimpun dana dari masyarakat dalam bentuk simpanan dan menyalurkannya kepada masyarakat dalam bentuk kredit atau bentuk-bentuk lainnya dalam rangka meningkatkan taraf hidup rakyat banyak.Dalam Undang-undang Nomor 10 Tahun 1998 tentang perbankan, menurut jenisnya Bank terdiri dari Bank Umum dan Bank Perkreditan Rakyat (BPR). Bank Perkreditan rakyat (BPR) adalah Bank yang melaksanakan kegiatan usaha secara konvensional atau berdasarkan prinsip syariah dalam kegiatannya tidak memberikan jasa lalu lintas pembayaran. Salah satu BPR di Indonesia adalah Bank Perkreditan Rakyat Harau Payakumbuh. 
Agar dapat melaksanakan tugas pokok dan mempertahankan kelangsungan BPR kepercayaan masyarakat sangat penting. Untuk memperoleh gambaran tentang perkembangan finansial suatu Bank, perlu mengadakan analisa atau interpretasi terhadap data finansial dari Bank bersangkutan, dimana data finansial tercermin di dalam laporan keuangan yang terdiri dari neraca, laporan laba rugi, laporan arus kas dan lain-lain.

Laporan keuangan merupakan data-data keuangan yang sifatnya kuantitatif yang menggambarkan kondisi keuangan dan hasil usaha suatu perusahaan pada saat tertentu atau jangka waktu tertentu. Dalam menjalankan usahanya sebagai lembaga keuangan kegiatan bank sehari-hari tidak terlepas dari bidang keuntungan. Dalam menganalisa dan menilai posisi keuangan untuk mengetahui seberapa jauh kemampuan Bank dalam menghasilkan keuntungan atau laba. Maka untuk mengukur keefektifan kegiatan operasional Bank dapat diketahui melalui rasio profitabilitas.

Pengertian rasio profitabilitas adalah rasio yang menunjukan kemampuan perusahaan untuk menghasilkan laba dari kegiatan operasionalnya. Sehingga hasil rasio profitabilitas dapat dijadikan gambaran tentang efektivitas kinerja bank ditinjau dari laba bersih yang diperoleh dibandingkan dengan biaya pendapatannya. Profitabilitas merupakan faktor yang seharusnya mendapat perhatian penting karena untuk dapat melangsungkan hidupnya, suatu bank harus berada dalam keadaan yang menguntungkan (profitable). Semakin besar profitabilitas berarti semakin baik, karena kemakmuran bank meningkat dengan semakin besarnya profitabilitas. Rasio profitabilitas terdiri atas Rasio Biaya Operasional, Net Profit Margin, Operating Income Ratio, Return On Asset dan Return On Equity.Berikut ini hasil dari perhitungan analisis ratio profitabilitas BPR Harau untuk periode 2012-2015.

Tabel 1.1

Perhitungan Analisis Rasio Profitabilitas Periode 2012-2015

\begin{tabular}{ccccc}
\hline Keterangan & $\mathbf{2 0 1 2}$ & $\mathbf{2 0 1 3}$ & $\mathbf{2 0 1 4}$ & $\mathbf{2 0 1 5}$ \\
\hline BOPO & $83,19 \%$ & $84,58 \%$ & $85,95 \%$ & $85,53 \%$ \\
NPM & $14,53 \%$ & $13,34 \%$ & $12,03 \%$ & $12,37 \%$ \\
ROA & $2,84 \%$ & $2,61 \%$ & $2,48 \%$ & $2,29 \%$ \\
ROE & $23,52 \%$ & $22,41 \%$ & $20,45 \%$ & $18,22 \%$ \\
\hline
\end{tabular}

Sumber : Data Olahan

BPR Harau Payakumbuh yang beralamat di Tanjung Pati Kecamatan Harau Kota Payakumbuh dalam ini laporan laba/rugi perusahaannya dalam posisi profitabilitas mengalami penurunan. Ini dapat dilihat BOPO tahun 2012 sampai 2014 mengalami kenaikan pada tahun 2014 BOPO (85,53\%) namun tahun 2015 BOPO $(85,53 \%)$ turun sebesar 0,42\%, NPM tahun 2012 sebesar (14,53\%) sedangkan tahun $2013(13,34 \%)$ turun sebesar 1,19\%, ROA pada tahun 2012 (2,84\%) sedangkan tahun $2013(2,61 \%)$ turun sebesar 0,23\%, ROE tahun 2012 sebesar(23,52\%) sedangkan tahun 2013 $(22,41 \%)$ turun sebesar $1,11 \%$.

\section{LANDASAN TEORI}

Menurut Munawir (2004:2) mengemukakan pengertian laporan keuangan sebagai berikut: "Laporan keuangan pada dasarnya adalah hasil dari proses akuntansi yang dapat digunakan sebagai alat komunikasi antara data keuangan atau aktivitas suatu 
perusahaan dengan pihak yang berkepentingan dengan data atau aktivitas dari perusahaan tersebut".

Selanjutnya menurut Harahap (2004:7) mengemukakan bahwa: "Laporan keuangan adalah merupakan pokok atau hasil akhir dari suatu proses akuntansi yang menjadi bahan informasi bagi para pemakainya sebagai salah satu bahan dalam proses pengambilan keputusan dan juga dapat menggambarkan indikator kesuksesan suatu perusahaan mencapai tujuannya".Adapun karakteristik dari laporan keuangan menurut Harahap 1997 adalah: dapat dipahami, relevan, keandalan, dan dapat diperbandingkan. Tujuan dari laporan keuangan menurut Harahap 1997 adalah

1. Untuk menyediakan informasi yang menyangkut kinerja serta perubahan posisi keuangan suatu perusahaan yang bermanfaat bagi sejumlah besar pengguna dalam pengambilan keputusan ekonomi.

2. Menunjukkan apa yang dilakukan manajemen (stewardship), atau pertanggungjawaban manajemen atas sumber daya yang dipercayakan kepadanya.

Pengguna dari laporan keuangan adalah Harahap 1997: investor, karyawan, pemberi pinjaman, pemasok dan kreditor usaha, pelanggan, pemerintah,dan masyarakat. Komponen darai laporan keuangan adalah: laporan posisi keuangan (neraca) pada akhir periode, aporan laba rugi komprehensif laba rugi dan penghasilan komprehensif lain selama periode tertentu, laporan perubahan ekuitas selama periode tertentu, laporan arus kas selama periode tertentu, catatan atas laporan keuangan, laporan posisi keuangan pada awal periode komparatif sebelumnya yang disajikan ketika entitas menerapkan suatu kebijakan akuntansi secara retrospektif atau membuat penyajian kembali pos-pos laporan keuangan.

Analisis laporan keuangan menurut Harahap (2006: 190) adalah sebagai berikut: "Analisis laporan keuangan yaitu menguraikan pos-pos laporan keuangan menjadi unit informasi yang lebih kecil dan melihat hubungannya yang bersifat signifikan atau yang mempunyai makna antara satu dengan yang lain baik antara data kuantitatif maupun data non-kuantitatif dengan tujuan untuk mengetahui kondisi keuangan lebih dalam yang sangat penting dalam proses menghasilkan keputusan yang sangat tepat".

Menurut Weston (1990), menjelaskan secara umum bahwa rasio keuangan dibagi menjadi 4 jenis, antara lain: rasio likuiditas, rasio solvabilitas, rasio aktivitas, dan rasio profitabilitas.

1. Rasio Likuiditas adalah rasio yang bertujuan untuk mengetahui kemampuan perusahaan dalam membayar kewajiban jangka pendek. Rasio likuiditas dibagi menjadi dua macam, antara lain sebagai berikut:a. Rasio Kas/Cash Ratio adalah perbandingan antara aktiva lancar yang paling likuid dengan total utang lancar. b. Rasio Lancar/Current Ratio adalah pengukuran yang digunakan secara luas untuk mengevaluasi likuiditas perusahaan dan kemampuan membayar utang jangka pendek. c. Rasio Cepat/Quick Ratio mengatakan bahwa rasio ini menunjukkan kemampuan aktiva lancar yang paling likuid mampu menutupi utang lancar.

2. Rasio Solvabilitas adalah menunjukan kemampuan perusahaan untuk memenuhi kewajiban keuangannya apabila perusahaan tersebut dilikuidasikan baik kewajiban keuangan jangka pendek maupun jangka panjang.Rasio solvabilitas dibagi menjadi lima macam, yaitu: a. Rasio Hutang/Total Debt to total Asset Ratio. Rasio total hutang dengan total aktiva yang biasa disebut rasio hutang, mengukur presentase besarnya dana yang berasal dari hutang.b. Rasio Laba terhadap Beban Bunga/Times Interest Earned, disebut rasio penutupan (coverage ratio). Ratio ini mengukur 
sejauh mana laba perusahaan boleh menurun tanpa mencoreng wajah keuangan perusahaan karena tidak mampu membayar beban bunga tahunan. c. Rasio Penutupan Beban Tetap/Fixed Charge Coverage, hampir sama dengan ratio laba terhadap beban bunga, akan tetapi dimasukkan beban lain dimana pada umumnya perusahaan menyewa aktiva (leasing) dan menanggung kewajiban jangka panjang atas dasar kontrak lease. d. Ratio Penutupan Arus Kas/Cash Flow Coverage Ratio, disini perusahaan harus mempunyai cukup arus masuk kas untuk dapat menutup semua pembayaran kewajiban arus kas setelah pajak dibayar.

3. Rasio Profitabilitas adalah menunjukan kemampuan perusahaan untuk menghasilkan laba selama periode tertentu. Rasio profitabilitas dibagi menjadi lima macam, yaitu: a. Marjin Laba atas Penjualan/Profit Marjin on Sales, marjin laba atas penjualan dihitung dari laba bersih sesudah pajak dibagi dengan penjualan, menghasilkan laba untuk setiap rupiah (atau satuan moneter lain) penjualan. b. Hasil Pengembalian atas Total Aktiva/Return On Total Assets, rasio ini mencoba mengukur efektivitas perusahaan dalam memanfaatkan seluruh sumber dayanya, yang kadang-kadang disebut dengan hasil pengembalian atas investasi (Return On Investmen/ROI). c. Hasil Pengembalian atas Modal/Return on Net Worth,ratio ini mengukur tingkat hasil pengembalian dari investasi para pemegang saham.

4. Rasio Aktivitas yaitu rasio yang mengukur seberapa efektif (hasil guna) perusahaan menggunakan sumber dayanya. Rasio Aktivitas diantaranya adalah: a. Perputaran Persediaan/Inventory Turnover, digunakan untuk mengukur kemampuan dana yang tertanam dalam persediaan yang berputar pada suatu periode tertentu, atau likuiditas dari persediaan dan tendensi adanya "overstock". b. Periode Penagihan Rata-Rata, rasio ini mengukur perputaran piutang, yang dihitung dalam dua tahap: (1) penjualan tahunan dibagi dengan 360 untuk mendapatkan penjualan harian ratarata dan, (2) piutang dibagi dengan penjualan harian rata-rata untuk memperoleh jumlah hari dimana penjualan terikat dengan piutang. Jumlah hari tersebut merupakan periode penagihan rata-rata, oleh karena merupakan lamanya waktu rata-rata bagi perusahaan harus menunggu menerima pembayaran setelah terjadi penjualan. c. Perputaran Aktiva Tetap/Fixed Assets Turnover, Ratio ini mengukur perputaran dari alat-alat dan mesin pabrik. d. Perputaran aktiva/Total Assets Turnover, digunakan untuk mengukur kemampuan dana yang tertanam dalam keseluruhan aktiva yang berputar pada suatu periode atau kemampuan modal yang diinvestasikan untuk menghasilkan "revenue".

Kinerja keuangan perusahaan menurut Munawir 2000, merupakan suatu gambaran tentang kondisi keuangan suatu perusahaan yang dianalisis dengan alat-alat analisis keuangan, sehingga dapat diketahui mengenai baik buruknya keadaan keuangan suatu perusahaan yang mencerminkan prestasi kerja dalam periode tertentu. Adapun manfaat dari penilaian kinerja keuangan perusahaan (Munawir: 2000) adalah sebagai berikut: Untuk mengukur prestasi yang dicapai oleh suatu organisasi dalam suatu periode tertentu yang mencerminkan tingkat keberhasilan pelaksanaan kegiatannya, untuk menilai kontribusi suatu bagian dalam pencapaian tujuan perusahaan secara keseluruhan, dapat digunakan sebagai dasar penentuan strategi perusahaan untuk masa yang akan dating, memberi petunjuk dalam pembuatan keputusan dan kegiatan organisasi pada umumnya dan divisi atau bagian organisasi pada khususnya, sebagai dasar penentuan kebijaksanaan penanaman modal agar dapat meningkatkan efisiensi dan produktivitas perusahaan. 
Tujuan penilaian kinerja perusahaan menurut Munawir (2000:31) adalah sebagai berikut: Untuk mengetahui tingkat likuiditas, untuk mengetahui tingkat solvabilitas, untuk mengetahui tingkat rentabilitas atau profitabilitas, yaitu menunjukkan kemampuan perusahaan untuk menghasilkan laba selama periode tertentu, untuk mengetahui tingkat stabilitas usaha, yaitu kemampuan perusahaan untuk melakukan usahanya dengan stabil.

Helfert (1996:67) menjelaskan penilaian kinerja keuangan suatu perusahaan merupakan salah satu cara yang dapat dilakukan oleh manajemen agar dapat memenuhi kewajibannya terhadap para penyandang dana dan juga untuk mencapai tujuan yang telah ditetapkan perusahaan. Penilaian kinerja perusahaan yang ditimbulkan sebagai akibat dari proses pengambilan keputusan manajemen, merupakan persoalan yang kompleks karena menyangkut efektivitas pemanfaatan modal dan efisiensi dari kegiatan perusahaan yang menyangkut nilai serta keamanan dari berbagai tuntutan yang timbul terhadap perusahaan.

Jadi dalam menilai kinerja keuangan perusahaan, dapat digunakan suatu ukuran atau tolok ukur tertentu. Biasanya ukuran yang digunakan adalah rasio atau indeks yang menghubungkan dua data keuangan. Adapun jenis perbandingan dalam analisis rasio keuangan meliputi dua bentuk yaitu membandingkan rasio masa lalu, saat ini ataupun masa yang akan datang untuk perusahaan yang sama.

\section{METODE PENELITIAN}

Dalam pengumpulan data dan bahan untuk melakukan penelitian ini, digunakan metode sebagai berikut :

1. Metode pengumpulan data

a. Studi Lapangan ( Field Research)

Peninjauan langsung ke objek penelitian di pilih untuk meneliti hasil data primer. Penelitian langsung ke lapangan ini akan dapat membantu penulis untuk melengkapi data yang diperlukan. Adapun cara riset lapangan ini adalah dengan mewawancarai pihak-pihak yang berkepentingan dalam hal ini adalah perusahaan atau instansi yang terkait.

b. Studi Kepustakaan ( Library Research )

Penelitian yang dilakukan ke perpustakaan beberapa buku-buku ilmiah dan tulisan-tulisan yang berhubungan dengan pembahasan yang dilakukan.

2. Metode Analisis Data

Dalam mengangalisa data, penulis menggunakan analisis data kualitatif dan kuantitatif. Dimana metode kualitatif menggambarkan, memahami dan menjelaskan data yang diteliti selama penelitian berlangsung, sedangkan metode kuantitatif menganalisa perhitungan tingkat profitabilitas pada PT. BPR Harau Payakumbuh.

Untuk memperoleh perkembangan atau kinerja hasil usaha suatu bank perlu diadakan suatu interpretasi atau analisa terhadap finansial bank yang bersangkutan. Dalam menganalisa dan menilai posisi keuangan untuk mengetahui seberapa jauh kemampuan bank dalam menghasilkan keuntungan atau laba. Maka untuk mengukur keefektifan kegiatan operasional bank dapat diketahui melalui rasio profitabilitas.

Rasio profitabilitas merupakan rasio untuk menilai kemampuan perusahaan dan mencari keuntungan. Penggunaan rasio profitabilitas dapat dilakukan dengan menggunakan perbandingan antara berbagai komponen yang ada dilaporan keuangan neraca dan laporan laba rugi. Pengukuran dapat dilakukan untuk beberapa periode. 
Penggunaan seluruh atau sebagian rasio profitabilitas tergantung dari kebijakan manajemen. Semakin lengkap jenis rasio yang digunakan semakin sempurna hasil yang akan dicapai. Artinya pengetahuan tentang kondisi dan posisi profitabilitas perusahaan dapat diketahui secara sempurna. Masing-masing jenis rasio profitabilitas digunakan untuk menilai serta mengukur posisi keuangan perusahaan dalam suatu periode tertentu untuk beberapa periode. Menurut Kasmi (2008:199) jenis-jenis rasio profitabilitas adalah:

1. Rasio Biaya Operasiona (BOPO)

Rasio biaya operasional adalah perbandingan antara biaya operasional dan pendapatan operasional. Rasio ini dapat dirumuskan sebagai berikut.

$$
\text { BOPO }=\frac{\text { Biaya operasional }}{\text { Pendapatan operasional }} \times 100 \%
$$

Rasio biaya operasional digunakan untuk mengukur tingkat efisiensi dan kemampuan bank dalam melakukan kegiatan operasinya. Mengingat kegiatan utama bank pada prinsipnya adalah berindak sebagai perantara, yaitu menghimpun dan menyalurkan dana (misalnya dana masyarakat), maka biaya dan pendapatan operasional bank didominasi oleh biaya bunga dan hasil bunga.

2. $\quad$ Net Profit Margin (NPM)

Net profit margin adalah rasio yang menggambarkan tingkat keuntungan (laba) yang diperoleh bank dibandingkan dengan pendapatan yang diterima dari kegiatan operasionalnya. Rasio ini dapat dirumuskan sebagai berikut.

$$
\mathrm{NPM}=\frac{\text { Laba bersih }}{\text { Pendapatan operasional }} \times 100 \%
$$

\section{Return On Assets (ROA)}

Rasio ini digunakan untuk mengukur kemampuan manajemen bank dalam memperoleh keuntungan (laba) secara keseluruhan. Semakin besar ROA suatu bank, semakin besar pula tingkat keuntungan yang dicapai bank tersebut dan semakin baik pula posisi bank tersebut dari segi penggunaan aset. Rasio ini dapat dirumuskan sebagai berikut.

$$
\mathrm{ROA}=\frac{\text { Laba bersih }}{\text { Total aktiva }} \times 100 \%
$$

Dalam rangka mengukur tingkat kesehatan bank terdapat perbedaan kecil antara perhitungan ROA berdasarkan teoretis dan cara perhitungan berdasarkan ketentuan Bank Indonesia. Secara teoretis, laba yang diperhitungkan adalah laba setelah pajak sedangkan dalam sistem CAMEL laba yang diperhitungkan adalah laba sebelum pajak.

4. Return on equity (ROE)

ROE adalah perbandingan antara laba bersih bank dengan modal sendiri. Rasio ini banyak diamati oleh para pemegang saham bank (baik pemegang saham sendiri maupun pemegang saham baru). Rasio ini dapat dirumuskan sebagai berikut.

$$
\mathrm{ROE}=\frac{\text { Laba bersih }}{\text { Modal sendiri }} \times 100 \%
$$

merupakan indikator yang amat penting bagi para pemegang saham dan calon investor untuk mengukur kemampuan bank dalam memperoleh laba bersih yang dikaitakan denga pembayaran deviden. Kenaikan dalam rasio ini berarti terjadi 
kenaikan laba bersih dari bank yang bersangkutan. Selanjutnya kenaikanLaba Bersih tersebut akan menyebabkan kenaikan harga saham bank.

\section{HASIL DAN PEMBAHASAN}

Profitabilitas adalah kemampuan bank untuk untuk memperoleh laba. Laba terdiri dari laba kotor, laba operasi, dan laba bersih. Dalam perhitungan rasio-rasio profitabilitas ini basanya dicari hubungan timbal balik antar pos yang terdapat pada laporan laba rugi dengan pos-pos pada neraca bank guna memperoleh berbagai indikasi yang bermanfaat dalam mengukur tingkat efisiensi dan profitabilitas bank yang bersangkutan.Adapun rumus-rumus perhitungan ratio profitabilitas bank yang sering digunakan adalah sebagai berikut:

a. Rasio Biaya Operasional (BOPO)

Rasio biaya operasional menunjukan perbandingan antara biaya operasional dan pendapatan operasional. Semakin kecil BOPO menunjukan semakin efisien bank dalam menjalankan aktivitas usahanya. Bank yang sehat rasio BOPO nya kurang dari Rp. 1,00 sebaliknya bank yang kurang sehat rasio BOPO nya lebih dari Rp. 1,00. Semakin tinggi biaya pendapatan maka bank menjadi tidak efisien.

$$
\text { BOPO }=\frac{\text { Biaya operasional }}{\text { Pendapatan operasional }} \times 100 \%
$$

Tabel 3.1

Perhitungan Rasio Biaya Operasional PT.BPR Harau Payakumbuh Tahun 2012-2015

\begin{tabular}{lllc} 
Tahun & $\begin{array}{c}\text { Biaya Operasional } \\
(\mathbf{1})\end{array}$ & \multicolumn{1}{c}{ Pendapatan Operasional } & $\begin{array}{c}\text { BOPO } \\
(\mathbf{2})\end{array}$ \\
\hline 2012 & Rp.8.616.149.738 & Rp. 10.358 .662 .944 & $83,19 \%$ \\
2013 & Rp.9.236.063.767 & Rp. 10.919 .941 .907 & $84,58 \%$ \\
2014 & Rp.9.530.709.622 & Rp. 11.088 .639 .695 & $85,95 \%$ \\
2015 & Rp.9.530.698.054 & Rp. 11.143 .362 .819 & $85,53 \%$ \\
\hline
\end{tabular}

Sumber : Data Olahan

a. Tahun 2012 BOPO $=\frac{8.616 .149 .738}{10.358 .662 .944} \times 100 \%=83,19 \%$

Berdasarkan perhitungan diatas tahun 2012 BOPO PT.BPR Harau Payakumbuh sebesar 83,19\% yang berarti bahwa Rp. 1,00 pendapatan operasional yang diterima berasal dari biaya operasional sebesar 0,8319 .

b. Tahun 2013 BOPO $=\frac{9.236 .063 .767}{10.919 .941 .907} \times 100 \%=84,58 \%$

BOPO tahun 2013 berarti bahwa kemampuan PT.BPR Harau Payakumbuh dalam melakukan kegiatan operasinya efisien, ini dapat dilihat dari BOPO sebesar 84,58\% dengan analisa bahwa setiap Rp. 1,00 pendapatan yang diterima berasal dari biaya operasional sebesar 0,8458 .

c. Tahun 2013 BOPO $=\frac{9.530 .709 .622}{11.088 .639 .695} \times 100 \%=85,95 \%$ 
BOPO tahun 2014 berarti bahwa kemampuan PT.BPR Harau Payakumbuh dalam melakukan kegiatan operasinya efisien, ini dapat dilihat dari BOPO sebesar 85,95\% dengan analisa bahwa setiap Rp. 1,00 pendapatan yang diterima berasal dari biaya operasional sebesar 0,8595 .

d. Tahun 2013 BOPO $=\frac{9.530 .698 .054}{11.143 .362 .819} \times 100 \%=85,53 \%$

BOPO tahun 2015 berarti bahwa kemampuan PT.BPR Harau Payakumbuh dalam melakukan kegiatan operasinya efisien, ini dapat dilihat dari BOPO sebesar $85,53 \%$ dengan analisa bahwa setiap Rp. 1,00 pendapatan yang diterima berasal dari biaya operasional sebesar 0,8553 .

Dari analisa BOPO dapat ditarik kesimpulan bahwa kinerja bank mengalami penurunan karena BOPO PT.BPR Harau Payakumbuh besar setiap tahunnya dari yang ditetapkan.

b. Net Profit Margin (NPM) Ratio

Net profit margin menggambarkan tingkat keuntungan (laba) yang diperoleh bank dibandingkan dengan pendapatan yang diterima dari kegiatan operasionalnya. Penilaian rata-rata ratio NPM menurut BI yaitu sebesar 10\% atau besar dari 0,1. Berdasarkan data yang diperoleh net profit margin PT.BPR Harau Payakumbuh selama tahun 2012 sampai dengan 2015 menggunakan rumus sebagai berikut.

$\mathrm{NPM}=\frac{\text { Laba bersih }}{\text { Pendapatan operasional }} \times 100 \%$

Tabel 3.2

Perhitungan Net Profit Margin PT.BPR Harau Payakumbuh

Tahun 2012-2015

\begin{tabular}{lccc}
\hline Tahun & $\begin{array}{c}\text { Laba Bersih } \\
(\mathbf{1})\end{array}$ & $\begin{array}{c}\text { PendapatanOperasional } \\
(\mathbf{2})\end{array}$ & $\begin{array}{c}\text { NPM } \\
(\mathbf{1 ~ : ~ 2 ~ ) \times 1 0 0 \%}\end{array}$ \\
\hline 2012 & Rp. 1.504 .886 .912 & Rp. 10.358 .662 .944 & $14,53 \%$ \\
2013 & Rp. 1.457 .043 .734 & Rp. 10.919 .941 .907 & $13,34 \%$ \\
2014 & Rp. 1.334 .164 .883 & Rp. 11.088 .639 .696 & $12,03 \%$ \\
2015 & Rp. 1.378 .729 .112 & Rp. 11.143.362.819 & $12,37 \%$
\end{tabular}

Sumber : Data Olahan

a. Tahun $2012 \mathrm{NPM}=\frac{1.504 .886 .912}{10.358 .662 .944} \times 100 \%=14,53 \%$

Berdasarkan perhitungan diatas tahun 2012 NPM PT.BPR Harau Payakumbuh sebesar $14,53 \%$ yang berarti bahwa Rp. 1,00 laba bersih yang diterima berasal dari pendapatan operasional sebesar 0,1453

b. Tahun $2013 \mathrm{NPM}=\frac{1.457 .043 .734}{10.919 .941 .907} \times 100 \%=13,34 \%$

NPM tahun 2013 berarti bahwa kemampuan PT.BPR Harau Payakumbuh efisien dalam melakukan kegiatan operasinya, ini dapat dilihat dari NPM 
sebesar 13,34\% dengan analisa bahwa setiap Rp. 1,00 laba bersih yang diterima berasal dari pendapatan operasional se besar 0,1334 .

c. Tahun 2014 NPM $=\frac{1.334 .164 .883}{11.088 .639 .696} \times 100 \%=12,03 \%$

NPM tahun 2014 berarti bahwa kemampuan PT.BPR Harau Payakumbuh efisien dalam melakukan kegiatan operasinya, ini dapat dilihat dari NPM sebesar 12,03\% dengan analisa bahwa setiap Rp. 1,00 laba bersih yang diterima berasal dari pendapatan operasional sebesar 0,1203 .

e. Tahun $2015 \mathrm{NPM}=\frac{1.378 .729 .112}{11.143 .362 .819} \times 100 \%=12,37 \%$

NPM tahun 2015 berarti bahwa kemampuan PT.BPR Harau Payakumbuh efisien dalam melakukan kegiatan operasinya, ini dapat dilihat dari NPM sebesar $12,37 \%$ dengan analisa bahwa setiap Rp. 1,00 laba bersih yang diterima berasal dari pendapatan operasional sebesar 0,1237.

Dari analisa NPM dapat ditarik kesimpulan bahwa kinerja bank mengalami penurunan.

c. Return On Assets (ROA)

Rasio ini digunakan untuk mengukur kemampuan manajemen bank dalam memperoleh keuntungan (laba) secara keseluruhan. Penilaian rata-rata rasio ROA menurut standar BI yaitu sebesar 0,5\% atau Rp. 0,005. Semakin besar ROA suatu bank, semakin besar pula tingkat keuntungan yang dicapai bank tersebut dan semakin baik pula posisi bank tersebut dari segi penggunaan aset. Berdasarkan data yang diperoleh return on assets PT.BPR Harau Payakumbuh selama tahun 2012 sampai dengan 2015 menggunakan rumus sebagai berikut.

$\mathrm{ROA}=\frac{\text { Laba bersih }}{\text { Total aktiva }} \times 100 \%$

Tabel 3.3

Perhitungan Return On Assets PT.BPR Harau Payakumbuh Tahun 2012-2015

\begin{tabular}{lccc}
\hline Tahun & $\begin{array}{c}\text { Laba Bersih } \\
(1)\end{array}$ & $\begin{array}{c}\text { Total Aktiva } \\
(2)\end{array}$ & $\begin{array}{c}\text { ROA } \\
(1: 2) \times 100 \%\end{array}$ \\
\hline 2012 & Rp.1.504.886.912 & Rp. 53.062.830.166 & $2,84 \%$ \\
2013 & Rp.1.457.043.734 & Rp. 55.764.396.114 & $2,61 \%$ \\
2014 & Rp.1.334.164.883 & Rp. 53.667.708.308 & $2,48 \%$ \\
2015 & Rp.1.378.729.112 & Rp. 60.280.671.231 & $2,29 \%$ \\
\hline
\end{tabular}

Sumber : Data Olahan

a. Tahun $2012 \mathrm{ROA}=\frac{1.504 .886 .912}{53.062 .830 .166} \times 100 \%=2,84 \%$

Berdasarkan perhitungan diatas tahun 2012 ROA PT.BPR Harau Payakumbuh sebesar 2,84\% yang berarti bahwa Rp. 1,00 laba bersih yang diterima berasal dari total aktiva sebesar 0,284. 
b. Tahun $2012 \mathrm{ROA}=\frac{1.457 .043 .734}{55.764 .396 .114} \times 100 \%=2,61 \%$

ROA tahun 2013 berarti bahwa kemampuan PT.BPR Harau Payakumbuh efisien dalam melakukan kegiatan operasinya, ini dapat dilihat dari ROA sebesar 2,61\% dengan analisa bahwa setiap Rp. 1,00 laba bersih yang diterima berasal dari total aktiva sebesar 0,261.

c. Tahun $2012 \mathrm{ROA}=\frac{1.334 .164 .883}{53.667 .708 .308} \times 100 \%=2,48 \%$

ROA tahun 2014 berarti bahwa kemampuan PT.BPR Harau Payakumbuh efisien dalam melakukan kegiatan operasinya, ini dapat dilihat dari ROA sebesar 2,48\% dengan analisa bahwa setiap Rp. 1,00 laba bersih yang diterima berasal dari total aktiva sebesar 0,248.

d. Tahun $2012 \mathrm{ROA}=\frac{1.378 .729 .112}{60.280 .671 .231} \times 100 \%=2,29 \%$

ROA tahun 2015 berarti bahwa kemampuan PT.BPR Harau Payakumbuh efisien dalam melakukan kegiatan operasinya, ini dapat dilihat dari ROA sebesar 2,29\% dengan analisa bahwa setiap Rp. 1,00 laba bersih yang diterima berasal dari total aktiva sebesar 0,229.

Dari analisa ROA dapat ditarik kesimpulan bahwa kinerja bank mengalami penurunan karena ROA PT.BPR Harau Payakumbuh turun setiap tahunnya. Semakin menurunnya laba bersih yang diterima dari total aktiva disebabkan karena terlalu besarnya kredit yang diberikan tidak diimbangi dengan pengembalian kredit yang mnyebabkan pendapatan bunga yang akan diterima menurun. Sehingga persentase laba bersih dibandingkan total aktiva menjadi sedikit.

d. Return On Equity (ROE)

ROE adalah perbandingan antara laba bersih bank dengan modal sendiri. Rasio ini merupakan indikator yang sangat penting bagi para pemegang saham dan calon investor untuk mengukur kemampuan bank dalam memperoleh laba bersih yang dikaitkan dengan pembayaran deviden. Penilaian rata-rata rasio ROE menurut standar BI yaitu 5\% atau 0,05 . Berdasarkan data yang diperoleh return on equity PT.BPR Harau Payakumbuh selama tahun 2012 sampai dengan 2015 menggunakan rumus sebagai berikut.

$$
\mathrm{ROE}=\frac{\text { Laba bersih }}{\text { Modal sendiri }} \times 100 \%
$$

Tabel 3.4

Perhitungan Return On Equity PT.BPR Harau Payakumbuh Tahun 2012-2015

\begin{tabular}{lccc}
\hline Tahun & $\begin{array}{c}\text { Laba Bersih } \\
(1)\end{array}$ & Modal Sendiri & ROE \\
& 2) & $(1: 2) \times 100 \%$ \\
\hline 2012 & Rp.1.504.886.912 & Rp. 6.398.591.098 & $23,52 \%$ \\
2013 & Rp.1.457.043.734 & Rp. 6.501.236.611 & $22,41 \%$ \\
2014 & Rp.1.334.164.883 & Rp. 6.524.062.133 & $20,45 \%$ \\
2015 & Rp.1.378.729.112 & Rp. 7.568.626.362 & $18,22 \%$ \\
\hline
\end{tabular}

Sumber : Data Olahan 
a. Tahun $2012 \mathrm{ROE}=\frac{1.504 .886 .912}{6.398 .591 .098} \times 100 \%=23,52 \%$

Berdasarkan perhitungan diatas tahun 2012 ROE PT.BPR Harau Payakumbuh sebesar 23,52\% yang berarti bahwa Rp. 1,00 laba bersih yang diterima diukur dari modal sendiri sebesar 0,2352.

b. $\quad$ Tahun $2012 \mathrm{ROE}=\frac{1.457 .043 .734}{6.501 .236 .611} \times 100 \%=22,41 \%$

ROE tahun 2013 berarti bahwa kemampuan PT.BPR Harau Payakumbuh efisien dalam melakukan kegiatan operasinya, ini dapat dilihat dari ROE sebesar $22,41 \%$ dengan analisa bahwa setiap Rp. 1,00 laba bersih yang diterima diukur dari modal sebesar 0,2241.

c. Tahun $2012 \mathrm{ROE}=\frac{1.334 .164 .883}{6.524 .062 .133} \times 100 \%=20,45 \%$

ROE tahun 2014 berarti bahwa kemampuan PT.BPR Harau Payakumbuh efisien dalam melakukan kegiatan operasinya, ini dapat dilihat dari ROE sebesar 20,45\% dengan analisa bahwa setiap Rp. 1,00 laba bersih yang diterima diukur dari modal sebesar 0,2045.

d. $\quad$ Tahun $2012 \mathrm{ROE}=\frac{1.378 .729 .112}{7.568 .626 .362} \times 100 \%=18,22 \%$

ROE tahun 2015 berarti bahwa kemampuan PT.BPR Harau Payakumbuh efisien dalam melakukan kegiatan operasinya, ini dapat dilihat dari ROE sebesar 18,22\% dengan analisa bahwa setiap Rp. 1,00 laba bersih yang diterima diukur dari modal sebesar 0,1822 .

Dari analisa ROE dapat ditarik kesimpulan bahwa kinerja bank mengalami penurunan karena ROE PT.BPR Harau Payakumbuh turun setiap tahunnya dari yang diharapkan. Semakin menurunnya laba bersih yang diterima dari modal sendiri disebabkan karena total pendapatan operasional yang menurun setiap tahunnya, dan biayabiaya operasional meningkat.

\section{SIMPULAN}

Berdasarkan hasil analisis pada halaman sebelumnya, dapat ditarik kesimpulan sebagai berikut :

Gambaran tingkat profitabilitas PT. BPR Harau Payakumbuh selama periode 2012 - 2015 dapat disimpulkan bahwa :

Tabel 3.5

PT. BPR Harau Payakumbuh

Perbandingan Rasio Profitabilitas Tahun 2012 - 2015

\begin{tabular}{lccccc}
\hline \multicolumn{1}{c}{ Rasio } & $\mathbf{2 0 1 2}$ & $\mathbf{2 0 1 3}$ & $\mathbf{2 0 1 4}$ & $\mathbf{2 0 1 5}$ & Rata industri \\
\hline Biaya Opearasional & $83,19 \%$ & $84,58 \%$ & $85,95 \%$ & $85,53 \%$ & $100 \%$ \\
Net Profit Margin & $14,53 \%$ & $13,34 \%$ & $12,03 \%$ & $12,37 \%$ & $10 \%$ \\
Return On Assets & $2,84 \%$ & $2,61 \%$ & $2,48 \%$ & $2,29 \%$ & $0,5 \%$ \\
Return On Equity & $23,52 \%$ & $22,41 \%$ & $20,45 \%$ & $18,22 \%$ & $5 \%$ \\
\hline
\end{tabular}


1. Dari rasio BOPO BPR Harau Payakumbuh tahun 2012 nilai BOPO sebesar $83,19 \%$, tahun 2013 nilainya sebesar 84,58\%, tahun 2014 nilanya sebesar $85,95 \%$, tahun 2015 nilainya sebesar $85,53 \%$. Bahwa untuk mengukur kemampuan pendapatan operasionalnya dalam menutup biaya operasional, semakin kecil BOPO semakin efisien bank tersebut mengendalikan biaya operasionalnya, maka keuntungan yang diperoleh bank akan semakin besar.

2. Dari rasio NPM BPR Harau Payakumbuh tahun 2012 nilainya sebesar 14,53\%, tahun 2013 nilainya sebesar 13,34\%, tahun 2014 nilainya sebesar $12,03 \%$, tahun 2015 nilainya sebesar 12,37\%. Sehingga kemampuan bank menurun dalam menghasilkan laba bersihnya. Apabila semakin besar akan semakin baik tetapi hal ini dapat dijadikan ukuran yang representatif, karena laba yang diperoleh tersebut juga harus dibandingkan dengan besarnya jumlah dana yang digunakan untuk memperoleh laba tersebut.

3. Dari rasio ROA BPR Harau Payakumbuh tahun 2012 nilainya sebesar 2,84\%, tahun 2013 ROA nilainya sebesar 2,61\%, tahun 2014 nilainya sebesar 2,48\%, tahun 2015 nilainya sebesar 2,29\%. Jadi ROA BPR Harau Paykumbuh menurun setiap tahunnya, walaupun demikian kinerja BPR Harau Payakumbuh tetap baik karena nilainya masih di atas rata-rata penilain BI. Apabila ROA semakin rendah bank tidak akan bisa beroperasi dengan efektif dan efisien dalam memanfaatkan asset yang dimilikinya dalam menghasilkan keuntungan.

4. Dari rasio ROE BPR Harau Payakumubuh tahun 2012 nilainya sebesar 23,52\%, tahun 2013 nilainya sebesar 22,41\%, tahun 2014 nilainya sebesar $20,45 \%$, dan tahun 2015 nilainya sebesar 18,22\%. Jadi dari tahun 2012 sampai tahun 2015 mengalami penurunan, sehingga kemampuan bank dalam mengasilkan laba bersih dari modalnya rendah. Namun ROE tersebut tetap dikatakan baik karena nilinya di atas rata-rata penilain BI.

\section{DAFTAR PUSTAKA}

Amelia, L., \& Marlius, D. (2018). Pengendalian Kredit Dalam Upaya Menciptakan Bank Yang Sehat Pada PT. Bank Pembangunan Daerah Sumatera Barat Cabang Utama Padang. https://doi.org/10.31227/osf.io/kpc64

Arifin, I. Z., \& Marlius, D. (2017). Analisis Kinerja Keuangan PT. Pegadaian Cabang Ulak Karang. https://doi.org/10.31227/osf.io/n2peu

Bank Indonesia, 2002. Studi Ekonomi Bantuan Profitabilitas Bank Indonesia, Jakarta

Dendawijaya, Lukman, 2009, “Manajemen Perbankan”, Ghalia Indonesia, Jakarta.

Hadayani, M., \& Marlius, D. (2017). Analisis Tingkat Kesehatan PT. BPR Batang Kapas. https://doi.org/10.31227/osf.io/bq48z 
Harahap, 2009, Analisis Laporan Keuangan, Edisi Ke-1, PT. Raja Grafindo Persada, Jakarta.

Ikatan Akuntan Indonesia, 2009, Pernyataan Standar Akuntansi KeuanganNo. 1, Revisi 2009, Dewan Standar Akuntansi Keuangan Ikatan Akuntan Indonesia, Jakarta.

Jumingan, 2011, Analisa Laporan Keuangan, Penerbit PT. Bumi Aksara, Jakarta.

Kasmir, 2002, Analisis Laporan Keuangan, Penerbit PT. Raja Grafindo Persada, Jakarta.

Munawir, 2002, Analisis Laporan Keuangan, Yogyakarta : Liberty.

Putri, Y. A., \& Marlius, D. (2018). Analisis Tingkat Kesehatan Bank Pada PT. Bank Perkreditan Rakyat (BPR) Jorong Kampuang Tangah Pariaman Cabang Padang. https://doi.org/10.31227/osf.io/r98pv

Rahmayeli, D. S., \& Marlius, D. (2017). Analisis Kinerja Keuangan Pada PT. Bank Perkreditan Rakyat (BPR) Batang Kapas Pesisir Selatan. https://doi.org/10.31227/osf.io/sz5db

Sartono, Agus, 2001, Manajemen Keuangan, BPFE, Yogyakarta.

Susilo, 2002, Panduan Praktis tentang kegiatan Bank Perkreditan Rakyat, Salemba Empat, Jakarta.

Undang-Undang Republik Indonesia No. 10 Tahun 1998, Tentang perubahan UndangUndang No. 7 Tahun 1992 Tentang Perbankan. http://www.bi.go.id 